\title{
*Haematological and Biochemical changes in experimentally infected local chickens with biting lice
}

Received : 7/12/2017

${ }^{1}$ Fatima Ibrahim Mohammad

${ }^{1}$ AL-Qadisyiah University/College of Science/Ecology Dept

${ }^{2}$ AL-Qadisyiah University/College of Education/Biology Dept

Accepted : 18/1/2018

Fatima.mohammad@qu.edu.iq

\begin{abstract}
The current study was designed to study the haematological and biochemical changes caused by experimentally infection with biting lice for the period from November 2013 to June 2014.

30 bird were taken from the chickens local chicks Gallus gallus domesticus aged one week purchased from local markets of AL-Diwaniya city divided into three groups included of each 10 birds (two experimentally groups and one control group) it was hit by lice from naturally infected chickens and then measured blood and biochemical parameters changes at the end of experiment about seven months.
\end{abstract}

The results showed of the blood parameters at end of the experiment significantly decreased in the number of red blood cells $2.29\left(\times 10^{6} / \mathrm{mm}^{3}\right)$, packed cell volume $37.99 \%$, Haemoglobin $9.52(\mathrm{~g} / \mathrm{dl})$ and Mean corpuscular Haemoglobin concentration $29.09(\mathrm{~g} / \mathrm{dl})$ while showed significantly increased in Mean corpuscular volume $143.23\left(\mu / \mathrm{m}^{3}\right)$, Mean corpuscular Haemoglobin 47.32(pg) and blood platelets $24.36\left(\times 10^{3} / \mathrm{mm}^{3}\right)$, and the results showed significantly increased in white blood cells count $144.05\left(\times 10^{3} / \mathrm{mm}^{3}\right)$, percentageMonocytes $9.10 \%$, Eosinophils $4.82 \%$, Neutrophils $2.80 \%$ and significantly decreased in percentage Lymphocytes67.43\%.

The results biochemical paramerters showed significantly decreased in Glucose and Cholesterol concentration and significantly increased in uric acid and Total protein concentration and nonsignificantly increased creatinin concentration.

key words: local chickens, biting lice, haematological changes, biochemical change

* The research is a part of M.Sc. dissertation in the first of the researcher

\section{Intoduction}

poultry infected many external parasites, including biting lice attacking chickens, especially in open education as in rural education and fields of poultry and is one of the most important factors affecting them (1). To external intrusion Ectoparasitism negatively affects the productive potential of the domestic chicken; they compete either on food Or cause stress to the birds and be these parasites are common in rural areas because of the lack of adequate housing for poultry in addition to lack concrete efforts to combat such scourges (2) Unlike 
commercial systems education censors on wild birds. External parasites may pose a problem in the transfer of many infectious diseases may also be the middle of a group of parasitic worms (3). Chicken body lice is Menacanthus stramineus of main types of lice that infects poultry, because it returns to the Palace of the life cycle of this kind of lice compared to other species of approximately 2-3 weeks they louse active and fast-moving (4,1). (5)showed the chicken infected with biting lice causes a decrease in the number of red blood cells and hemoglobin ratio and increase the average hemoglobin sphere $(\mathrm{MCH})$ Carpuscular Mean Haemoglobin, haemoglobin guide $\mathrm{Hb} 1$ also leukocyte cell count rises especially leukocyte Eosinophils and Monocytes macrophages percentage only while the proportion of Lymphocytes.

\section{Materials and Methods}

\section{Experimental Design}

We got 30 chicks of domestic chicken Gallus gallus domesticus the age of one week from the local markets in the city of Diwaniya, for the purpose of conducting laboratory experiment to study the blood and biochemical changes caused by injury experimental Biter lice. As well as six adults birds of the same type infected with lice-intensive for the purpose of causing infection in experimental chick.

study was conducted in the laboratory of parasites-animal House-biology Department of the duration of the experiment from 1-11-2013 to1-62014.used 30 chicks type Gallus gallus domesticus one week old and was healthy good and free from external and internal parasite through macroscopic examination and microscopic examination of feces for a week, put in three Cages, each cage 1 meter length and width of 0.5 meters and a height of 1 meter carpeted floor sawdust
(6) Explained having anaemia in birds infected with the blood-sucking ectoparasites (ticks and dream) with a decrease in the percentage of blood cells stack size (PCV) and reduced the total number of red blood cells Erythrocytes or a decrease in the percentage of hemoglobin $(\mathrm{Hb})$ especially in infected chickens by ectoparasites severe injury were observed an increase in the total number of white blood cells, Leucocytosis and increase in proportion as Heterophilia variables Eosinophilia cells in chicken infected with ticks ; lice and Mites with malnutrition and breeding.

thickness of $4 \mathrm{~cm}$ approx. Then chicks were distributed into three groups, two groups experimental and one control group, each with 10 chick, chicks were given the prefix diet until the age of 20 days and then replaced with diet B final. The water has been introduced in the Fountains of plastic capacity (1 liter) .The experiment design based on (7) with some modification, as follows:

1-taking 30 birds from chick embryos aged one week and placed in cages prepared for this purpose and described above.

2-divided into three groups two groups experimental (each group included 10 chicks) and the group's control included (10 chicks) and left for a week under control and the conditions are ideal . 
3-placed three adult chickens from the naturally infected chickens with each set of totals for the experiment for a week after which excluded the infected chickens and left for seven months .

\section{Collection of blood samples}

After the expiration of a model experiment taking blood $(5 \mathrm{ml})$ of each bird, one for testing blood parameters as drawing blood from a vein from the area under the wing by 'syringe' sterile blood was added to the container, a plastic tube on EDTA (weatherproof material anticoagulant with a slight shake of pipes) ( 8 ) and record the number of animal, for the purpose of the study of blood traits and is counting red and white blood total and and the concentration of hemoglobin and the size packed cells volume (PCV), White blood cells differential using blood 4-draw blood from the two experimental groups both and control group in the end of the experiment amounting to seven months and measured blood and biochemical parameters

analyzer device. The second specimen was placed in special tubes for blood collection (non-container blocker clotting) and left at room temperature until coagulation and then put to a centrifugal fast $3000 \mathrm{r} / \mathrm{min}$ for 10 minutes and then pull the serum by a pipette and transfer to plastic bottles clean then closed tightly and stored in the refrigerator at a temperature of -20 until a biochemical analyzes using plus ${ }^{\circledR}$ Reflotron device. As well as the same method was conducted on the control group for the purpose of comparison.

\section{statistical analysis}

Test results statistically using a t-test to determine the significant differences below the level of probability $(\mathrm{P} \geq 0.5)$ As stated in (9).

\section{Results}

\section{Haematological parameters}

\section{1 red blood cells count $\left(\mathrm{RBCs}\left(\mathrm{x} 10^{6} / \mathrm{mm}^{3}\right)\right.$}

Table shows (1) the effect of lice infection in the red blood count of control birds the results showed no significant differences $(\mathrm{P} \geq 0.5)$ between the experiment group and the control group when applying the test $\mathrm{t}$, the mean of experimental group showed a significant decrease compared with the mean of a control group .vkd group had an average experience group $2.29 \times 10^{6} / \mathrm{mm}^{3}$ compared with $3.11 \times 10^{6} / \mathrm{mm}^{3}$ for the control group

\subsection{The concentration of hemoglobin Haemoglobin (mg / dL)}

Indicates the table (1) the effect of lice in the concentration of hemoglobin birds experiment group. The results show significant differences $(\mathrm{P} \geq 0.5)$ between the experiment group and the control group when applying the test $t$, average test group showed a significant decrease compared with the control group average. It was an average experience range $9.52 \mathrm{mg} / \mathrm{dL}$ with $12.82 \mathrm{mg} / \mathrm{dL}$ for the control group. 


\subsection{Packed cell volume of blood cells (\%PCV)}

Table (1) the Packed cell volume group experiment, the results showed a significant difference $(\mathrm{P} \geq 0.5)$ between the experiment group and the control group when applying the test $t$, mean showed a significant decrease experiment group

\section{4. mean corpuscular volume (MCV) $(\mu \mathrm{m} 3)$}

Table shows (1) the size of the red globule rate (MCV) birds experiment group. have the results of the statistical analysis showed a significant difference $(P \geq 0.5)$ between the experiment group and the control group when applying the test $t$, showed the average test group rose

\subsection{Mean Corpuscular Haemoglobin (MCH)}

Results set out in Table (1) to the concentration of red blood cell hemoglobin $\mathrm{MCH}$ rate (pg). The results showed a significant difference between the experiment group and the control group and the comparison using the $t$ test show a significant rise $(\mathrm{P} \geq 0.5)$ in the average compared with the control group mean . the average experimentale group 37.99\% compared with $40.34 \%$ for the control group.

significantly compared with the average control group, it was Average experience group 143.23 microliter/ mm 3, compared with 129.16 microliter / $\mathrm{mm} 3$ for the control

group.

experiment group compared with the average control group had an average of $47.32 \mathrm{pg}$ experiment group compared with $41.42 \mathrm{pg}$ for the control group.

\subsection{Mean corpuscular Haemoglobin Concentration $(\mathrm{MCHC})(\mathrm{g} / \mathrm{dL})$}

The results of the Mean corpuscular Haemoglobin Concentration (MCHC) rate shown in the table (1) to the existence of significant differences between the two groups of experiment and control. In applying the t-test showed a significant decrease $\quad(\mathrm{P} \geq 0.5) \quad$ in the average experiment group compared with the control group average, it was an average experience groups $29.09 \mathrm{~g} / \mathrm{dL}$, compared with $32.11 \mathrm{~g} / \mathrm{dL}$ for the control group

\subsection{The average number of platelets $(\mathrm{PLT})\left(\mathrm{X10}{ }^{3} / \mathrm{mm}^{3}\right)$}

Table shows (1), platelet count rate (PLT). The results showed significant differences $(\mathrm{P} \geq 0.5)$ between the experiment group and the control group and when comparison test using $\mathrm{t}$, average test group showed a significant increase compared with the average control group. The mean test set $24.36 \times 10^{3} / \mathrm{mm}^{3}$ compared with $13.08 \times 10^{3}$ / $\mathrm{mm}^{3}$ for the control group.

\subsection{The number of cells white blood (WBCs Count) $\left(\mathrm{x10}^{3} / \mathrm{mm}^{3}\right)$}


Table shows (1) the effect of lice in the number of blood cells, white birds experiment group. results of statistical analysis showed significant differences $(\mathrm{P} \geq 0.5)$ between the experiment group and the control group when applying the t-test

\subsection{1.percentage of Lymphocytes(\%)}

Table (1) influence of lice in the percentage of lymphocytes to experience group birds. statistical analysis results showed moral differences ( $\mathrm{P} \geq 0.5)$ between a trial and control when applying $t$ test, showed the average experience of moral 1.8.2.Monocytes(\%)

Results indicate percentage of single cells and shown in the table (1) to moral differences between the two groups of experiment and control, applying $\mathrm{t}$ test showed high $(\mathrm{P} \geq 0.5)$ in average

\subsubsection{Eosinophils cells (\%)}

Cell percentage results indicate Eosinophils as shown in the table (1) to significant differences $(\mathrm{P} \geq 0.5)$ between the two sets of experiment and control, applying $t$ test showed a rise in the average

\subsubsection{Neutrophils (\%)}

Table (1) percentage of cells equivalents for a group experience, results showed moral differences $(\mathrm{P} \geq 0.5)$ between a trial and a group control when applying $t$ test, showed the average higher significant
, average test group showed a significant increase compared with the control group. the mean experience group $144.05\left(\times 10^{3} /\right.$ $\mathrm{mm}^{3}$ ) compared with $123.43\left(\times 10^{3} / \mathrm{mm}^{3}\right)$ for the control group. decline group compared with the control group, the average experience group $67.43 \%$ compared with $83.37 \%$ of the control group.

experience group compared with the control group average, the average experience Group 9.10\% compared with $7.26 \%$ for the control group.

significantly of experience group compared with the control group average was average $4.82 \%$ experience group compared to $1.80 \%$ for the control group.

experience group compared with the control group average was $2.80 \%$ average experience group compared with $1.8 \%$ for the control group.

Table (1): reflects the changes in local chicken blood standards experimentally infected lice biter after 7 months of experience

\begin{tabular}{|l|l|l|}
\hline $\begin{array}{l}\text { Non infected chickens(control) } \\
(10 \text { BIRDS })\end{array}$ & $\begin{array}{l}\text { infected } \\
\text { 20)chickens(experiment) } \\
\text { (BIRDS }\end{array}$ & parameters \\
\hline
\end{tabular}




\begin{tabular}{|l|l|l|}
\hline 123.43 & $144.05^{*}$ & WBC $\left(\mathrm{x} 10^{3} / \mathrm{mm}^{3}\right)$ \\
\hline \hline 83.37 & $67.43^{*}$ & Lymphocytes(\%) \\
\hline \hline 7.26 & $9.10^{*}$ & Monocytes(\%) \\
\hline \hline 1.80 & $4.82^{*}$ & Eosinophils(\%) \\
\hline \hline 1.8 & $2.80^{*}$ & Neutrophils(\%) \\
\hline \hline 0.0 & 0.0 & Basophils $(\%)$ \\
\hline \hline 3.11 & $2.29 *$ & RBC $\left(\mathrm{x} 10^{6} / \mathrm{mm}^{3}\right)$ \\
\hline \hline 129.16 & $143.23^{*}$ & MCV $\left(\mu \mathrm{m}^{3}\right)$ \\
\hline \hline 41.42 & & MCH $(\mathrm{pg})$ \\
\hline \hline 32.11 & $47.32^{*}$ & MCHC(g/dl) \\
\hline \hline 40.34 & $29.09^{*}$ & P.C.V(\%) \\
\hline \hline 12.82 & $37.99 *$ & Hb $(\mathrm{g} / \mathrm{dl})$ \\
\hline \hline 13.08 & $9.52^{*}$ & \\
\hline
\end{tabular}

*Differences significant between the study groups at risk $p \geq 0.5$ using test $t$.

Numbers Indicates the represent mean.

\section{Biochemical parameters}

\subsection{Glucose concentration in blood serum $(\mathrm{mg} / \mathrm{dl})$}

The results showed in the table (2) significant differences $(\mathrm{P} \geq 0.5)$ between the experiment and control groups when applying $\mathrm{t}$ test, showed the average experience of moral decline group compared with the control group average. It was an average experience group 190.7 $\mathrm{mg} / \mathrm{dL}$ compared with $209.8 \mathrm{mg} / \mathrm{dl}$ for control group. 
2.2 cholesterol concentrationin in blood serum $(\mathrm{mg} / \mathrm{dl})$

Results showed in the table (2) significant differences $(\mathrm{P} \geq 0.5)$ in cholesterol concentration between the experiment and control groups when applying $\mathrm{t}$ test, showed the average experience group of significant decline compared with the control group average and experience group was $86.1 \mathrm{mg} / \mathrm{dL}$ compared with $93.1 \mathrm{mg} / \mathrm{dl}$ for control group.
The results showed in the table (2) significant differences $(\mathrm{P} \geq 0.5)$ between the experiment and control groups when applying $\mathrm{t}$ test, showed the average experience group higher significant compared with the control group average and experience group was $8.4 \mathrm{mg} / \mathrm{dL}$ compared with $3.7 \mathrm{mg} / \mathrm{dl}$ for control group.

\subsection{Total protein concentration in blood serum $(\mathrm{mg} / \mathrm{dl})$}

The results showed in the table(2) significant differences $(\mathrm{P} \geq 0.5)$ between the experiment and control groups when applying $t$ test, showed experience group average higher significant with average control group, it was an average experience group $41.5 \mathrm{mg} / \mathrm{dL}$ compared with $35.5 \mathrm{mg} / \mathrm{dl}$ for control.

\section{5. creatinine Concentration in blood serum (mg/dl)}

Table (2) showed presence a slight increase in the concentration of creatinine in serum experiment group compared to the control group but did not reach the degree of significant when applying $t$ test
$(\mathrm{P} \geq 0.5)$ average was $0.3 \mathrm{mg} / \mathrm{dL}$ for experience group , $0.1 \mathrm{mg} / \mathrm{dl}$ for control group.

Table (2): reflects the biochemicals changes in local chicken blood infected .experimentally with lice biter after 7 months of experience

\begin{tabular}{|c||c|c|}
\hline Control group (10 birds) & Experiment $\quad\left(\mathbf{2 0} \begin{array}{c}\text { birds) } \\
\text { group }\end{array}\right.$ & parameters \\
\hline 209.8 & $190.7^{*}$ & Glucose( mg/dl ) \\
\hline 93.1 & $86.1^{*}$ & cholesterol ( mg/dl ) \\
\hline 3.7 & $8.4^{*}$ & Uric acid ( mg/dl) \\
\hline \hline 35.5 & $41.5^{*}$ & Total protein ( mg/d) \\
\hline
\end{tabular}




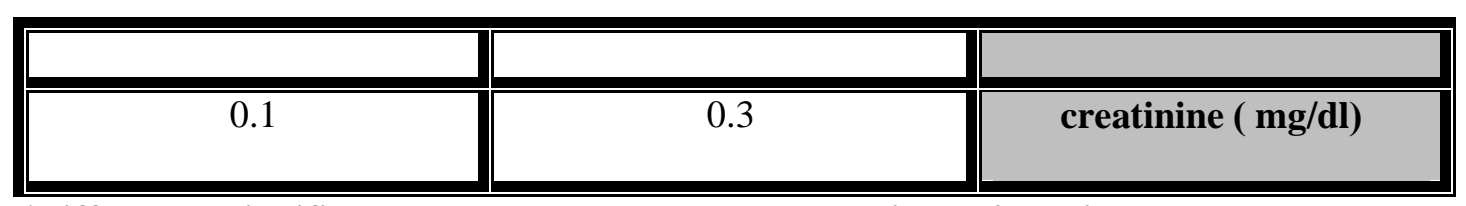

*differences significant between the study groups at risk $p \geq 0.5$ using test $t$.

Numbers Indicated the represent mean.

\section{Disscussion}

\section{Haematological parameters}

the results of current study showed to a significant decrease in the number of red blood cells (RBC) and the size of compact blood cells (PCV) and the concentration of hemoglobin $(\mathrm{Hb})$ in the chicken group infected experimentally with biter lice reaching $2.29\left(\mathrm{X}_{10}^{6} / \mathrm{mm}^{3}\right)$ and $37.99 \%$ and 9.52 (mg / dL), respectively, compared with the control group, which amounted to $3.11\left(\mathrm{X}^{6} 0^{6}\right.$ / $\mathrm{mm}^{3}$ ) and $40.34 \%$ and $12.82(\mathrm{mg} / \mathrm{dL})$, respectively, and this is consistent with $(10,5,6)$ as digs chicken body lice M.stramineus feather sweat and feeding on the blood of the candidate and thus gets anemia (11), may be due cause of poverty blood in the chicken to absorb the blood by ectoparasites, especially in very dense infections( $12,13,14)$.

As for thrombocytopenia were observed and no significant increase in the average number of platelets, reaching $24.36\left(\mathrm{X} 10^{3} / \mathrm{mm}^{3}\right)$ in the test set, compared with the $13.08\left(\mathrm{X}^{3} 0^{3} / \mathrm{mm}^{3}\right)$ in the control group and the reason Alyhdot Resume wounds Self-wounding caused by itching and scratching and scratches skin (11), therefore increasing platelet satisfactorily as a result of the body is exposed to bleed hemorrhage and wounds Trauma which are known to increase the number of platelets Thrombocytosis (15). the results of current study showed to a significant increase in the number of white blood cells in the test set, reaching 144.05 $\left(\mathrm{X} 10^{3} / \mathrm{mm}^{3}\right)$ compared with $123.43\left(\mathrm{X} 10^{3}\right.$ $\left./ \mathrm{mm}^{3}\right)$ in control group agrees with $(16,5,13,6)$, as the reason for the high number of white blood cells due to inflammation caused by the presence of foreign parasitic infections (14), with longer infections are one of the important defenses that birds owned agnist ectoparasites blood sucking (17).The high Eosinophils cells ratio, which stood at $4.82 \%$ in the test set, compared with $1.80 \%$ for the control group and back caused by the Immunoactivation which occurs as a result of feeding the lice on the host's blood (18), as the rising proportion of cells Eosinophils in response to the presence of biter lice and external parasites other $(7,1920,21)$.

Results of the study also indicated to a significant increase in the proportion of neutrophils reaching in experience group $2.80 \%$ compared with $1.8 \%$ for the control group and the reason for this to inflammation and stress resulting from the presence of parasitic infections (22), where the neutrophil is the body's first line of defense

(23). 
Also been noted as a significant increase in Monocytes ratio reaching in a group experiment $9.10 \%$ compared with $7.26 \%$ for the control group and is due to inflammation where monocytes attack inflammation areas and digest the dead cells and foreign materials immediately after the neutrophils therefore considered the line second of defense (23).
The Lymphocytes, the study showed the occurrence of a significant decrease in the test set, reaching $67.43 \%$ compared with the control group, which amounted to $83.37 \%$ the reason is due to the stress which urges Immunosupression (24), where reduces the stress of the level of immunity in animals infected and result in an increase in the level of the hormone Corticosternoe change, neutrophils and lymphocytes cells ratio $(25,26)$.

chickens group experimentally lice, reaching $41.5(\mathrm{mg} / \mathrm{dL})$ as compared to control, which amounted to $35.5(\mathrm{mg} / \mathrm{dl})$ and is due to the fact that proteins are essential to the sustainability of power defense of the body against infections and manufacture of materials needed for the defense of the body such as antibodies that work against the attacking materials (23).

The results of the study showed the occurrence of significant increase in the concentration of uric acid in the blood serum, reaching in the experiment group ( $8.4 \mathrm{mg} / \mathrm{dL})$ compared with $(3.7 \mathrm{mg} / \mathrm{dl})$ for the control group because of the occurrence of histological changes in the kidney represented atrophy and severe necrosis in the lining of her cells with the presence of severe bleeding in the kidney tissue, as stated (7) infestation of lice cause poisoning chicken body chickens, including kidney and thus a defect in kidney function (30) that the severe crash in kidney tissue leads to increased concentration of uric acid.

Also the results showed of the current study, a rise in the concentration of creatinine in serum This is due to the emergence of large amounts of creatinine in the case of severe muscle damage (31). Also (32) if creatinine concentration in plasma above the normal limit rose the this is a sign of decline in kidney filtration rate, 
because creatinine based on kidney filtration in the purge. The reason for the decline in kidney filtration rate of the college to the tissue changes caused by the presence of toxins and inflammation caused by infection and thus change and inefficient functions.

\section{References}

1.Amen, Khalse and ahamd hamd, Riad. (2007). MES h watch khis to types of repression for local chicken in Erbil. Iraqi Journal of veterinary science, 21:13-21.

2.Mungube E O, Bauni S M, Muhammed L, Okwach E W, Nginyi J M and Mutuoki T. K.(2006). A survey of the constraints affecting the productivity of the local scavenging chickens in the Kionyweni cluster, Machakos District. KARI Katumani, Annual Report 2005.

3.Arends, J. J. (2003). External parasites and, poultry pests. In: Diseases of poultry.

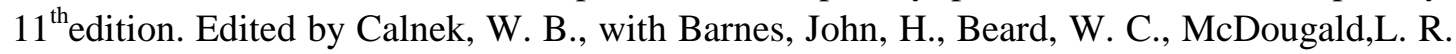
and Saif, Y. M. Iowa State Press, Blackwell Publishing Company, Ames,Iowa. P 905- 930.

4.Wall,R.andShearer,D.(1997).Veterinary Entomology Arthropod Ecto-parasites of veterinary Importance .Chapman \& Hall,p.151.

5.Groseva,N.\&Gundasheva,P.P.(2002).Haematologicalchangesinchicken,experimentally infected with biting lic (phthiraptera:Insecta) Bulg. J.Vet.Med. 5(1):23-28.

6.AL-Saffar,T.M. and AL-Mawla,E.D.(2008).Some haematological changesinchickensinfectionwithectoparasitesin Mosul,Iraq.J.Vet.Sci,22(2):95-100.

7.Prelezov,P.N.;Groseva,N.I.andGoundasheva,D.I.(2006).Patho-

morphological changes in the tissues of chicken,experimentally infected with biting lice (Insecta:Phthiraptera)Vet Arhiv,76:207-215.

8.Campbell, T.W.(1995).Avian haematology and cytology. $2^{\text {nd }}$ ed.Iowa State Uni.press,Ames.

9. Al-Rawi, khashee Mahmoud. (2000). Interance into statistics. House of books would deter sellers, , Mosul, Iraq, Second Edition: 469 pages.

10.AL-Nakshabandy, A.A.R.(2002).The prevalenceof ectoparasites and haemoprptozoal diseases of fowl in Erbil government ,Iraq. M. Sc. Thesis, Univ. of Salahaddin, Iraq.

11.Jacob, J. P.; Wilson, H. R.; Miles, R. D.; Butcher, G. D. and Mather, F. B. (2003).Factors affecting egg production in backyard chicken flocks. Institute of food and agricultural sciences (IFAS) extension. University of Florida. Fact sheet PS-35.

12.Jordan, FTW. And Pattison,M.(1996). Poultry Diseases $4^{\text {th }}$ ed,Bailliere Tindal, London,WB saunders, 287-289.

13.Campell.TW.(2004). Avian Hematology and Cytology $2^{\text {nd }}$ ed.Iwoa State Press, Blackwell publishing company: 12 .

14.Rick, L.C. and Elsevier,M.(2004). Veterinary clinical pathology secrets $2^{\text {nd }}$ ed, Elesier Mosby Missouri :282-301.

15.Geetha,N.(2010).Textbook of Medicalphysiology, $2^{\text {nd }}$ ed,Hayderabad,India.p683. 
16.Strukie,P.D.(1976). Avian physiology $3^{\text {rd }}$ ed,springer verlag, New York,Berlin: 45-69.

17.Wikel,S.K.(1996).The Immunology of Host-Ectoparasitic Arthropod Relationships, CAB International.

18.Maxwell,M.H.(1987). The avian eosinophil-A review. World's poultryscience J. 43. 190-207.

19.Prelezov,P.N.;Gundasheva,D.IandGroseva,N.I(2002).Haematological changes in chickens experimentally infected with biting lice (phthiraptera:Insecta). Bulgarian Journal of Veterinary Medicine 5:29-38.

20.Saino,N.;Moller,A.P. and Bolzern,A.M.(1995).Testosterone effects on the immune system and parasite infestations in the Barn Swallow (Hirudo rustica):An experimental test of the immune competence hypothesis. Behavioral Ecology 6: 397-404.

21.Saino,N.;Galza,S. and Moller,A.P.(1998).Effects of dipteran ectoparasite on immune response and growth trade-offs in Barn Swallow, Hirundo rustica, nestlings. Oikos 81 :217-228.

22.Ots,I.;Murumagi,A. and Horak,P.(1998).Haematologicalhealth stateindices of reproducing great tits :methodology and sources of natural variation-functional ecology.12: 700-707.

23.Arabs, Yusuf Mohamed, krmashah, Farouk nag me, science and MSG, Sabah Nasser Yas links, $m$ Habib Abdul Rahim. (1989). animal physiology. Ministry of higher education and scientific research. jamBaghdad. Pete wisdom. 483 pages.

24.Horak,P.;Tegelmann,L;;Ots,I.\& Moller,A.P.(1999).immune function and survival of great tit nestlings in relation to growth conditions- Oecologia 121: 316-322.

25.Newman, S. H.; Carter, H. R.; Whitworth, D. L and Zinkl, J. G. (2006). Health assessments and stress response of xantus's Murrelets to capture,handlingandradio-marking.MarineOrnithology33:147-154.

26.Gross,W.BandSiegel,H.S.(1983).Evaluationof the heterophil/lymphocyte ratio as a measure of stress in chickens. Avian Diseases 27: 972-979.

27.Freeman,B.M.(1970).Carbohydrate stores in chickens infected with Eimeria tenella.Parasitology,61(1):245-251.

28.Machado,C.M.(2002).CrescimentodoTecidoAdipose.In:Macari,M.;Furlan,R.L.and Gonzales,E.Fisiologia aviaria aplicada a frangos de corte .Jaboticabal:FUNEP-UNESP.p375.

29.Freitas,FLC.; Almeida,KS.; Machado, RZ. and Machado,CR.(2008). Lipid and GlucoseMetabolismofbroilers(Gallusgallus domesticus)Experimentallyinfectedwith EimeriaacervulinaTyzzer,1929.Oocysts.BrazilianJ.ofpoultryscience,V.10,N.3.:157-162.

30.Siller, W.G.(1983).Structure of the kidney .In:Freeman BM,editor. Physiology and biochemistryof the domestic fowl. vol. 4. New York: Academic Press: p. 91-105.

31.Hochleithner M.(1994). Biochemistries. In: Ritchie BW, Harrison GJ, HarrisonLR, editors. Avian medicine Principles and application. LakeWorth:WingersPublishing.p.223-45.

32.Abdallah, shteiwi. (2012) Physiology. Department of Biological Sciences University of Jordan. Oman - March House Publishing .534 page. 


\section{"التغيرات الدموية والكيموحيوية في الاجاج المحلي المصاب تجريبياً بالقمل}

العاض

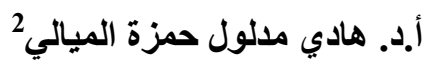

\author{
1 فاطمة إبراهيم محمد 1 ف \\ 1 جامعة القادسية /كلية العلوم/ قسم البيئة \\ 2جامعة القادسية/ كلية التربية/قسم علوم الحياة
}

Fatima.mohammad@qu.edu.iq

المستخلص

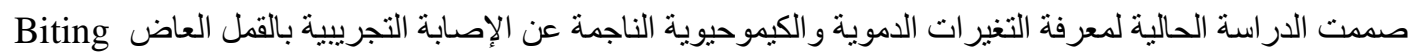

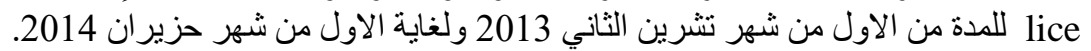

شملت الدراسة 30 طير اً من أفراخ الدجاج المحلي Gallus gallus domesticus بعمر اسبو ع واحد نم شر اؤها من

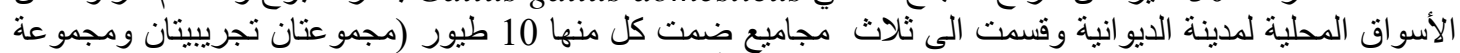

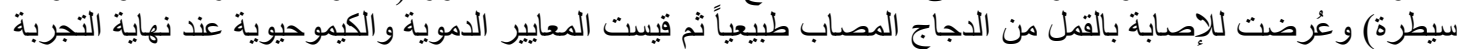

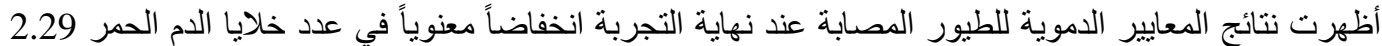

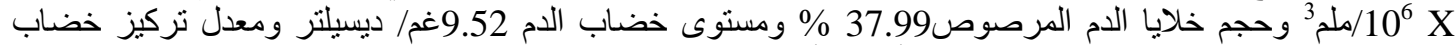

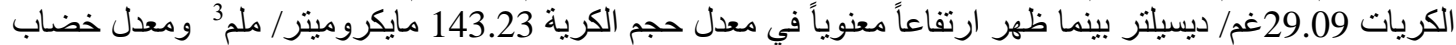

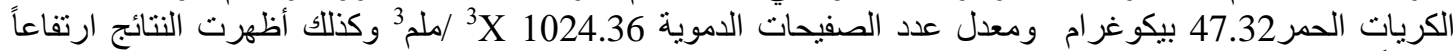

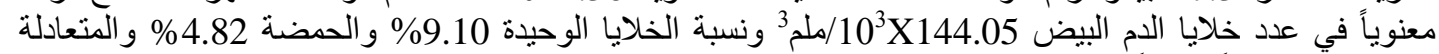

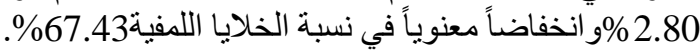

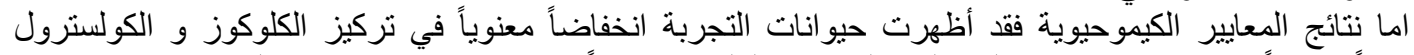

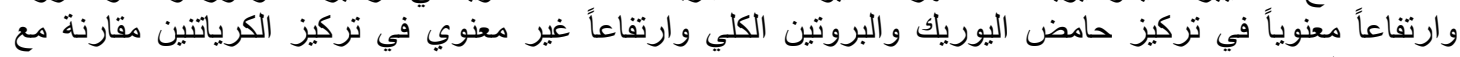

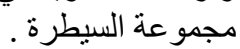

الكلمات المفتاحية: الاجاج المحلي، القمل العاض، التغيرات الاموية، التغيرات الكيموحيوية. 
* البحث مستل من رسالة ماجستير للباحث الاول 